\title{
GÊNERO E SEXUALIDAdE: O PODER TRANSFORMADOR DA EDUCAÇÃO
}

\author{
Cássia de Lourdes Batista* \\ Camila dos Santos Vitello** \\ Milena Bastos Da Silva***
}

\begin{abstract}
RESUMO
A sociedade foi construída a partir de relações de poder que trataram de segregar e marginalizar alguns grupos. A escola, coexistindo nesse contexto, pode mover-se para a ruptura das desigualdades. Dessa maneira, viabilizar a temática de gênero e sexualidade no cotidiano escolar colabora com uma educação transformadora, voltada ao respeito, à valorização das inúmeras vivências de gênero e sexualidade e ao combate à violência. Frente à possibilidade de intervenção e sem adotar uma postura ingênua de que a instituição escolar é capaz de mudar toda uma sociedade, pode-se afirmar que ela detém poder de transformação na vida dos indivíduos? Para fundamentar essa discussão, contamos com o apoio teórico de autores(as) como Louro (2014), Freire (2019), Hooks (2017), Moreno (1999), entre outros. A fim de alcançar os objetivos desta investigação, foi realizada uma pesquisa de caráter qualitativo, por meio de livros, artigos e dados. Entre outras questões, a pesquisa evidenciou a historicidade presente nos assuntos de gênero e sexualidade nas escolas brasileiras e no currículo formativo, refletindo sobre a responsabilidade do fazer educacional diante do compromisso de uma educação não discriminatória e transformadora.

Palavras-chave: Escola. Gênero. Sexualidade. Currículo. Educação transformadora.
\end{abstract}

* Mestranda em Educação pela UMESP, especialista em Neuropsicopedagogia, docente do curso de Pedagogia da UMESP, docente e vice-diretora da escola Municipal em São Bernardo do Campo. cassia.batista@metodista.br .

** Pedagoga.

*** Pedagoga.

Revista Páginas de Filosofia, v. 10, n. 1, p. 137-171, jan.-jun. 2021 


\title{
GENDER AND SEXUALITY: THE TRANSFORMING POWER OF EDUCATION
}

\begin{abstract}
Society was built from power relations that tried to segregate and marginalize some groups. The school, coexisting in this context, can move towards the rupture of inequalities. In this way, making the theme of gender and sexuality viable in everyday school life collaborates with a transformative education, focused on respect, valuing the countless experiences of gender and sexuality and combating violence. Faced with the possibility of intervention and without adopting a naive attitude that the school institution is capable of changing an entire society, can it be said that it has the power to transform the lives of individuals? To support this discussion, we have the theoretical support of authors such as Louro (2014), Freire (2019), Hooks (2017), Moreno (1999), among others. In order to achieve the objectives of this investigation, a qualitative research was carried out, through books, articles and data. Among other issues, the research highlighted the historicity present in the issues of gender and sexuality in Brazilian schools and in the training curriculum, reflecting on the responsibility of doing education in the face of the commitment to a non-discriminatory and transformative education.
\end{abstract}

Key-words: School. Genre. Sexuality. Resume. Transformative education.

\section{INTRODUÇÃo}

Existe hoje, no Brasil, uma estigmatização social sobre a possibilidade de inserção das temáticas pertinentes ao gênero e a sexualidade na educação. Nos deparamos com uma rejeição no que tange o assunto, pautadas em visões distorcidas do que é a sua tratativa. Entretanto, junto à rejeição que se atribui ao tema, temos um apreensivo cenário de violência de gênero e problemáticas em torno da sexualidade que reforçam as desigualdades. Considerando a responsabilidade da escola no processo de formação do ser humano, é concebível que ela pode influenciar de maneira negativa quando reproduz, no fazer pedagógico, padrões discriminatórios e discursos que fortalecem as distinções sociais.

As inadequações no que diz respeito à tratativa do assunto e sua incorporação no currículo educacional faz com que sua relevância seja

Revista Páginas de Filosofia, v. 10, n. 1, p.137-171, jan.-jun. 2021 
omitida. Contudo, abordar os conteúdos das diversidades, com foco em gênero e sexualidade, possivelmente viabilize o olhar crítico-reflexivo do(a) aluno(a), sua construção como sujeito disposto de autonomia e autoestima, a naturalização das inúmeras expressões, e incentive práticas individuais e coletivas que minimizem as discriminações e violências presentes na sociedade, reconhecendo a qualidade do respeito, promovendo a valorização do autocuidado e dignificando as diversas formas de existir.

Dessa maneira, este estudo justifica-se pela urgência na abordagem crítica e responsável de gênero e sexualidade na escola, temática que ainda demanda muitas discussões, e o rompimento dos paradigmas que a permeia, principalmente quando se trata do potencial das escolas diante a possibilidade de transgredir as desigualdades institucionalizadas.

Então, tratando da coexistência de gênero, sexualidade e educação: de que maneira a construção histórica acerca do tema influencia na prática educacional? Qual a relevância de abordar temas que estão incorporados às vivências da comunidade escolar? Sem adotar uma postura ingênua de que a instituição escolar é capaz de mudar toda uma sociedade, pode-se afirmar que ela detém poder de transformação na vida dos indivíduos?

Uma possível resposta para estes questionamentos talvez esteja intrínseca ao fato de que a construção sócio-histórica estigmatizou o gênero e a sexualidade e naturalizou padrões de existências androcêntricos e heteronormativos, marginalizando identidades que não correspondem aos modelos aceitos e prejudicando todos os campos de sociabilidade, inclusive o ambiente educacional e os mecanismos que o engendram.

Diante de tais considerações, esta pesquisa pretende, portanto, elucidar a relevância da abordagem de gênero e sexualidade nas escolas, romper com os estigmas que permeiam o assunto e refletir sobre o potencial transformador da educação no desenvolvimento de sujeitos legitimados, críticos e responsáveis por práticas não discriminatórias.

Para responder às questões evidenciadas, este estudo, de caráter qualitativo, trará um levantamento bibliográfico coletado através de livros, artigos e dados.

Revista Páginas de Filosofia, v. 10, n. 1, p. 137-171, jan.-jun. 2021 
A pesquisa qualitativa responde a questões muito particulares. Ela se preocupa, nas ciências sociais, com um nível de realidade que não pode ser quantificado. Ou seja, ela trabalha com o universo de significados, motivos, aspirações, crenças, valores e atitudes, o que corresponde a um espaço mais profundo das relações, dos processos e dos fenômenos que não podem ser reduzidos à operacionalização de variáveis. (MINAYO, 2001, p. 21)

A pesquisa apresenta considerações de Louro (2014), Freire (2019), Hooks (2017), Moreno (1999), entre outros(as) autores(as), por se tratar de estudiosos(as) que discorrem sobre a necessidade do rompimento de paradigmas discriminatórios e sexistas nas escolas e abordam a concepção do professor(a) frente à prática pedagógica, propondo uma educação dialógica.

Conforme já mencionado, este tema evidencia a necessidade de um debate assíduo sobre a importância de agregar os assuntos de gênero e sexualidade no currículo educacional brasileiro, visto que estão incorporados às vivências da comunidade escolar. Pensamos que a escola, como ambiente socioeducativo, detém um papel relevante na construção de uma sociedade inclusiva, integrada e autocrítica, sendo assim, a abordagem desse tema atua no combate à violência, na redução de atitudes preconceituosas, na valorização da liberdade das múltiplas maneiras de existir e, consequentemente, na humanização e sentimento de pertencimento de todas as pessoas.

Frente ao exposto, este estudo segue estruturado em três seções, a primeira, "Gênero e sexualidade" trata da construção histórica de gênero e sexualidade e apresenta a dimensão da violência e das adversidades no cenário brasileiro que acomete a existência dos sujeitos que contrariam o modelo vigente. A segunda, "Gênero, sexualidade e educação" traz a historicidade da temática no Brasil e aborda as caracterizações e reflexões do tema no ambiente escolar, na legislação e no currículo. Por fim, a terceira seção, "Gênero e sexualidade na escola: um diálogo necessário" aborda a responsabilidade social da escola, o que é de fato abordar o tema no contexto educacional e o potencial transformador de uma educação em gênero e sexualidade. 
As considerações finais conduzem as principais reflexões que o estudo possibilitou evidenciar.

Nesse sentido, espera-se que esta pesquisa possa contribuir com uma perspectiva transgressora, voltada à ressignificação de condutas, de modo que os sujeitos respeitem a si e aos outros e tenham seus direitos assegurados.

\section{GÊNERO E SEXUALIDADE}

\subsection{GÊNERO E SEXUALIDADE: O QUE É ISSO?}

Ao nascermos, uma das primeiras respostas atribuídas a nossa existência é dada ao questionamento "É menino ou menina?", o que é chamado de sexo biológico. Temos características biológicas que variam dependendo de aspectos hormonais e cromossômicos, por exemplo. Essas variações biológicas existem, mas como são interpretadas? Os órgãos genitais foram nomeados, diferenciações sobre o que é ser homem e o que é ser mulher foram socialmente construídas e foram estabelecidos os atributos da masculinidade e da feminilidade, portanto considera-se o que são "coisas de menino" e "coisas de menina". Foi naturalizado um modelo binário de existência, que consiste na oposição dos gêneros homem/mulher e na heterossexualidade, que é a prática sexual exclusivamente entre indivíduos do sexo oposto, como única forma de manifestação sexual possível. Essa composição atravessa as relações humanas e as desigualdades existentes.

Sendo assim, torna-se necessário o questionamento: o que é o gênero e a sexualidade? São conceitos que possuem amplas e polissêmicas definições. Na virada do século XIX para o XX, o feminismo como movimento social organizado adquiriu visibilidade ao incorporar reinvindicações relacionadas, por exemplo, ao direito das mulheres de estudar, de ter acesso a algumas profissões e o direito ao voto (movimento que foi nomeado de "sufragismo"). Esse cenário de manifestações, que a princípio eram pautadas no interesse das mulheres brancas e de classe média, foi considerado a "primeira onda" do feminismo. Na chamada "segunda onda", com início na década de 1960, além das reinvindicações políticas e sociais, começaram as produções teóricas 
do movimento feminista. Com isso, o conceito de gênero passou a ser indagado (LOURO, 2014).

0 gênero começou a ser percebido como socialmente construído, baseado no sexo biológico. Foram instituídas as representações de cada gênero e naturalizada a ideia de que há elementos inerentes às vivências das mulheres e outros às vivências dos homens. Portanto, há diversos comportamentos que, ao serem historicamente produzidos e reproduzidos, configuram o gênero masculino e feminino. Nessa concepção a biologia não é rejeitada, considera-se que há um processo de construção histórica que legitima diferenciações entre homens e mulheres a partir de suas características biológicas, ou seja, o gênero como construção sócio-histórica e o sexo como algo naturalmente dado.

Após a segunda onda, junto com o pós-estruturalismo, iniciaram-se novas discussões que abrangeram o gênero, uma das notáveis estudiosas dentro desse debate é Joan Scott, historiadora que contribui significativamente às formulações teóricas a respeito. Ela faz uma crítica ao binarismo homem-mulher implícito no conceito "gênero", como se houvesse apenas uma única forma de expressão da masculinidade e feminilidade, pois essa lógica dicotômica desconsidera outras relações de poder que transpõe o convívio social (LOURO, 2014):

Os sujeitos que constituem a dicotomia não são, de fato, apenas homens e mulheres, mas homens e mulheres de várias classes, raças, religiões, idades, etc. e suas solidariedades e antagonismos podem provocar os arranjos mais diversos, perturbando a noção simplista e reduzida de "homem dominante versus mulher dominada". (LOURO, 2014, p. 37, grifo da autora).

Então, ao mesmo tempo que uma visão rígida e polarizada difere mulheres e homens, ela iguala as mulheres em única categoria, «o retorno ao determinismo biológico do qual se quer escapar mantém-se presente nessa lógica (igualdade na diferença), dando a entender que há algo fixo e imutável que se aplicaria a todas as mulheres» (SCOTT, 2002 apud TONELI, 2012, p. 150).

Portanto, não é possível pensar o gênero sem considerar as diversas formas de opressão e os variados arranjos sociais de classes, raças, 
sexualidades, subjetividades e histórias de vida, pois isso tornaria o discurso do gênero uma pauta exclusivamente branca, heterossexual e de classe média. Além disso, debates teóricos, como os defendidos por Linda Nicholson e Judith Butler, começaram a problematizar a ideia do sexo como algo natural. Ao questionar o binarismo sexual, é possível compreender que além do gênero, o sexo é também uma construção social, uma ação performática, de modo que há outras culturas que interpretam e categorizam as variações biológicas de outras maneiras (NICHOLSON, 2000 apud TONELI, 2012).

A partir do século XVll, o pensamento ocidental passou a considerar as diferenciações biológicas como determinantes na distinção dos corpos masculinos e femininos, foram dados diferentes nomes aos órgãos sexuais e começaram a enxergar nessas diferenças anatômicas uma oposição, ascendendo a noção binária de identidade sexual (LACQUER, 2001 apud TONELI, 2012). Ao final do século XVIII, a sexualidade passou a ser vigiada e controlada (TONELI, 2012), a feminilidade ou masculinidade se tornaram a verdadeira essência da identidade, diretrizes do que pertence ao "universo" feminino e ao masculino começaram a ser impostas e reproduzidas, junto a isso, a naturalização da heterossexualidade. Foram estabelecidos padrões comportamentais correspondentes a cada sexo e normatizadas as experiências sexuais reprodutoras e heterossexuais. Ou seja, qualquer maneira de vivenciar a sexualidade e performar um gênero, que difere dessas deliberações sociais, passou a ser tratada como anormal e irregular (TONELI, 2012). Para Louro "a atribuição da diferença está sempre implicada em relações de poder, a diferença é nomeada a partir de um determinado lugar que se coloca como referência." (2014, p. 50).

Logo, dado esse lugar de referência binária e heteronormativa ${ }^{1}$, foram classificadas as perversões, as sexualidades desviantes e improdutivas. Como é o caso dos sujeitos LGBT's (Lésbicas², Gays ${ }^{3}$, Bis-

\footnotetext{
1 Heteronormativa: é a característica da sociedade que supõe os desejos e atitudes heterossexuais como padrão de normalidade.

2 Lésbica: pessoa que se identifica como mulher e sente atração por outras mulheres.

3 Gay: pessoa que se identifica como homem e sente atração por outros homens.
} 
sexuais ${ }^{4}$, Transexuais ${ }^{5}$ e Travestis $^{6}$ ), que compõem um arranjo diverso de vivências de gênero e sexualidade.

\subsection{LGBTFOBIA}

A população LGBT integra um grupo diverso de pessoas as quais suas maneiras de vivenciar a sexualidade e o gênero foge do que se considera uma normalidade social, e por não se enquadrarem em um padrão binário e heterossexual são socialmente estigmatizadas, sofrendo, cotidianamente, com o ódio e a violência consequente dessa discriminação.

A sociedade brasileira, através da regulação dos corpos, normatizou as maneiras de viver e subalternizou existências que não seguem essa ordem social heteronormativa, refletindo no que hoje é chamado de homofobia, que consiste em ações discriminatórias voltadas à comunidade LGBT (SOBRAL; SILVA; FERNANDES, 2019). Essas ações e violências acontecem em múltiplos âmbitos, como discursos discriminatórios, agressões verbais, segregação e exclusão nos espaços e instituições sociais, violência física e psicológica, podendo chegar a situações extremas como homicídios (FREIRE; CARDINALI, 2012).

No Brasil colônia, a exemplo, com a influência de ensinamentos cristãos, os homossexuais eram chamados de sodomitas, que se refere à prática sexual que não possui a finalidade de reprodução, contrariando o que eles admitiam como sendo a natureza humana. Esse pensamento culminou na criminalização da prática homossexual, tendo como consequência a pena de morte (FREIRE; CARDINALI, 2012).

No século XIX, houve a patologização da homossexualidade, surgindo o termo homossexualismo, deixando então de ser considerada um crime para ser considerada uma doença que precisava ser entendida e curada. Mesmo com a descriminalização, conceber a prática homossexual uma doença engendrou inúmeros discursos, teorias, ideias e ações eugenistas que oprimiu e deslegitimou as existências dessas

4 Bissexual: pessoa que sente atração tanto por homens quanto por mulheres.

5 Transexual: pessoa que tem identidade de gênero diferente da que lhe foi atribuída ao nascer, refere-se à como a pessoa se sente, se mostra para o mundo e realmente é.

6 Travesti: pessoa que constrói sua identidade de acordo com a concepção de feminino manifestado na sociedade. 
pessoas. Acreditava-se que a homossexualidade poderia motivar a prática de crimes como abuso infantil, e surgiram até propostas de cura baseadas em educar para que se segue a normalidade social e forçar homossexuais a se relacionarem com pessoas do sexo oposto (FREIRE; CARDINALI, 2012).

Nos anos 80, o avanço da epidemia de HIV/AIDS no Brasil só acentuou a visão social preconceituosa com relação à população LGBT, uma vez que consideraram que um dos principais grupos de risco da doença eram os homossexuais. Tornaram-se comuns discursos que defendiam que a doença seria um castigo divino para pessoas que não viviam sua sexualidade de acordo com os princípios religiosos, reforçando a estigmatização das vivências consideradas desviantes da normalidade (VILLARINHO; PADILHA, 2016).

Foi a partir da década de 1990 que houve um aumento de atuações e organizações de grupos militantes, encorajados à luta social por direitos e pela necessidade de orgulho e visibilidade da população LGBT (FREIRE; CARDINALI, 2012). Essa atuação foi fundamental para algumas conquistas em escala nacional e também internacional, como a retirada da homossexualidade da Classificação Estatística Internacional de Doenças e Problemas Relacionados à Saúde (CID) pela Organização Mundial da Saúde (OMS), que aconteceu em 1990 (MAIA, 2020). Em 2013, ocorreu a aprovação do casamento civil entre pessoas do mesmo sexo pelo Conselho Nacional de Justiça (CNJ) (FARIA, 2018). Houve a definição do Supremo Tribunal Federal (STF) no direito da troca de nome no registro civil para transexuais, em 2018 (POMPEU, 2018). E, também em 2018, a OMS deixou de caracterizar a transexualidade como doença (BENITO, 2018). Contudo, mesmo com os avanços no que tange seus direitos e visibilidade, a comunidade LGBT segue socialmente segregada e sofrendo diariamente com múltiplas violências historicamente estruturadas.

No Brasil, segundo dados do Relatório do Grupo Gay da Bahia $(\mathrm{GGB})^{7}$, a cada 26 horas um LGBT é assassinado ou se suicida vítima de LGBTfobia. Em 2019, foram 329 mortes violentas de pessoas dessa

Fundado em 1980, o Grupo Gay da Bahia é a mais antiga associação de defesa dos direitos humanos dos homossexuais no Brasil. 
comunidade, sendo o país com maior número de crimes contra LGBT's, podendo esses números serem maiores devido a subnotificação. Mais da metade dos assassinatos LGBT's no mundo acontecem aqui, no Brasil. É relatado também que os(as) transexuais são mais vulneráveis às mortes violentas (ABGLT, 2016) e, de acordo com o boletim da Associação Nacional de Travestis e Transexuais (ANTRA), até o dia 31 de outubro de 2020, houve um aumento de $47 \%$ nos assassinatos de pessoas trans, se comparado ao ano de 2019, sendo 151 casos (ANTRA, 2020).

Para os LGBT's, o ambiente educacional, assim como outros espaços sociais, é também opressor e excludente. Segundo dados da Pesquisa Sobre o Ambiente Educacional, na escola, 73\% dos(as) estudantes LGBT's sofreram agressões verbais e 1/4 foram agredidos(as) fisicamente, além da defasagem de acolhimento adequado e omissão por parte das instituições de ensino nessas situações (ABGLT, 2016). É essencial considerarmos que essas violências se tornam ainda mais expressivas com as intersecções de raça, etnia, regionalidade, entre outros aspectos (SILVA; MIRANDA; SANTOS, 2020). Dessa forma, é possível refletir o quão necessário é que os assuntos acerca da discriminação e das violências decorrentes dela adentrem as salas de aula, através de uma visão humana, crítica e responsável.

\subsection{VIOLÊNCIA DE GÊNERO}

A teorização do conceito de gênero, concebida na década de 1960 por estudiosos e militantes feministas, promoveu um desdobramento significativo no que tange à compreensão do termo e o avanço pelo rompimento de paradigmas tradicionais. Em contraposição às perspectivas analíticas que apresentavam as diferenças reduzidas ao âmbito biológico (LOURO, 2014), os estudos feministas se voltaram à percepção de gênero como estrutura social.

É necessário demonstrar que não são propriamente as características sexuais, mas é a forma como essas características são representadas ou valorizadas, aquilo que se diz ou pensa sobre elas que vai construir, efetivamente, o que é feminino ou masculino em uma dada sociedade e em um dado momento histórico. (LOURO, 2014, p. 25). 
Representações de feminilidade e masculinidade foram determinadas num protótipo hierárquico. Em detrimento desse sistema, a construção social dos papéis femininos, corroborados pela masculinidade hegemônica, submeteu as mulheres a posições de inferioridade. A sistematização da ideologia dominante definiu o espaço doméstico como o único lugar de atuação feminina, negou às mulheres direito sobre o próprio corpo e restringiu sua participação institucional (HOOKS, 2020). Louro (2014, p. 21) elucida que, "a segregação social e política a que as mulheres foram historicamente conduzidas tivera como consequência a sua ampla invisibilidade como sujeito". Nessa perspectiva, a identidade estereotipada vinculada ao sentido do feminino, passou a legitimar a ocultação da mulher, de modo que as diferenciações sociais fossem naturalizadas.

Tais estereótipos foram institucionalizados como condutas em todos os campos de sociabilidade, sejam eles, políticos, educacionais ou religiosos, e passaram a delimitar a forma como os sujeitos existem no mundo. "Além de serem regras restritivas [...] as normas de gênero são também a base para muitas situações de desigualdade". (LINS; MACHADO; ESCOURA, 2016, p. 10).

No Brasil, estudos revelam que os estigmas produzidos consolidaram a violação dos direitos das mulheres. Em 2019, o Fórum Brasileiro de Segurança Pública apresentou dados coletados para a 13a edição do Anuário Brasileiro, de acordo com as estatísticas, em 2018, 1.206 mulheres foram vítimas de feminicídio, 61\% eram negras e 70,7\% tinham baixo nível de escolaridade, além disso, 80,8\% dos casos foram cometidos pelo companheiro ou ex-companheiro da vítima. Também foram registrados 263.067 casos de lesão corporal dolosa, um registro a cada dois minutos. (BRASIL, 2019).

Em 2018, o índice apontou 66.041 ocorrências de violência sexual, sendo $81,8 \%$ vítimas do sexo feminino. Além disso, 53,8\% dos casos foram enquadrados como estrupo de vulnerável. (BRASIL, 2019). Em relação ao mercado de trabalho, embora haja a participação ativa das mulheres, a ocupação em cargos gerenciais é, exponencialmente, abaixo da ocupação dos homens. Em 2016, dados indicaram que as mulheres atuaram, aproximadamente, $73 \%$ a mais de horas do que 
os homens em atividades de cuidados ou serviços domésticos. $\mathrm{Na}$ política, em 2017, havia 10,5\% de representação feminina na câmara dos deputados. A desigualdade salarial também acomete a existência feminina. (IBGE, 2018).

0 recorte racial é um fator fortemente influente no que tange à historicidade da violência de gênero. As mulheres negras são mais vitimizadas em todas as esferas da vida pública e privada, "[...] a exemplo de se encontrarem em espaços de trabalhos mais precarizados, índices baixos de escolaridade e altas taxas de Chefia familiar, dentre tantas outras questões" (SANTIAGO, 2019, p. 45). Diante disso, ao falar da violência de gênero, é imprescindível considerar outras intersecções como raça, classe social e etnia.

Percebe-se assim, que a condição da mulher no Brasil contemporâneo retrata os efeitos da opressão sexista e da negligência do Estado em relação às políticas públicas. Desse modo, faz-se necessário compreender a forma como as relações de gênero são produzidas (e reproduzidas) e impulsionar discussões acerca do tema, tendo como propósito combater a violência de gênero.

Diante desse contexto, Louro (2014) chama a atenção para o modo como a escola atua na produção das diferenças e a importância de se pensar em práticas educativas que impeçam a continuidade dos paradigmas vigentes. E que, contribuir para a desconstrução dos estereótipos de gênero possibilitaria aos alunos e alunas a valorização das diferenças, a ruptura de atitudes discriminatórias e viabilizaria transformações sociais.

\subsection{Abuso Infantil, IST E OUTRAS QUESTões FUndAMENTAis}

A construção social da sexualidade e as redes de poder que a envolvem resultaram em inúmeras problemáticas nas relações humanas, em esfera coletiva e individual, que interferem em múltiplos elementos da saúde, segurança, direitos e integridade do indivíduo. Nesse sentido, a gravidez na adolescência é uma questão psicossocial que acomete a biografia de diversos sujeitos. 0 número de casos revela a dimensão do assunto e a ausência de medidas voltadas à informação e ao diálogo sobre o tema. Segundo o Ministério da Saúde, todos os dias, aproxima- 
damente, 930 adolescentes e jovens têm filhos no Brasil, tornando-se 434,5 mil por ano. Ainda que tenha tido queda, o índice nacional é descomunal, sendo 68,4 nascimentos para cada mil adolescentes, com idade entre 15 e 19 anos, contra 46 nascimentos do índice mundial. (OLIVEIRA, 2020).

Considerando a especificidade da adolescência e os fatores que a cercam, a gravidez precoce é passiva de riscos psicológicos e fisiológicos, tanto para a grávida quanto para o recém-nascido. Nesse sentido, alguns desses problemas como, aborto, hipertensão, anemia, depressão, eclampsia e desnutrição, afetam as meninas durante e depois do estado gravídico (BELARMINO et al., 2009 apud DIAS; TEIXEIRA, 2015). É importante ressaltar que há casos em que a gravidez precoce é resultado de violação sexual, fator que compromete ainda mais o estado de saúde da vítima.

Em relação à saúde do nascido, pode ocorrer morte perinatal, prematuridade, transtornos do desenvolvimento, deficiências e epilepsia. (AQUINO-CUNHA et al., 2002 apud DIAS; TEIXEIRA, 2010). No Brasil, a taxa de mortalidade do recém-nascido nesses casos é de 15,3 óbitos para cada mil nascidos vivos. (BRASIL, 2020).

Ainda de acordo com os autores, a gravidez na adolescência nem sempre é um acontecimento indesejado, às vezes, "é tida como uma via de acesso a um novo estatuto de identidade e de reconhecimento através do papel materno" (DIAS; TEIXEIRA, 2010, p. 129). Desse modo, faz-se necessário compreender as diferentes perspectivas que circundam a vida das adolescentes.

Essa questão é prevalente nas camadas socioeconomicamente mais baixas, de vulnerabilidade social e baixo nível de escolaridade. Nesse contexto, a vida escolar, principalmente das meninas, é afetada (OLIVEIRA, 1998). E, muitas vezes, há renúncia da possibilidade de estruturação de um projeto de vida estável.

Os tabus sociais, culturais e religiosos atribuídos à sexualidade dificultam discussões capazes de minimizar a dimensão da gravidez precoce. A falta de informação, acolhimento, comunicação e programas governamentais voltados à conscientização corrobora com a estigmatização do assunto. É importante que as intervenções educacionais 
ultrapassem as informações restringidas aos métodos contraceptivos e busquem abordar questões naturais da vida sexual, além disso, apresentem os sentidos e as consequências da gravidez e da maternidade, considerando também, o papel paternal. (DIAS; TEIXEIRA, 2010).

Ao falar sobre contracepção, muitos sujeitos direcionam suas preocupações estritamente à gravidez, ignorando a extensão alarmante das Infecções Sexualmente Transmissíveis (IST). A esse respeito, as IST são um problema de saúde pública que assolam a sociedade há muito tempo. De acordo com o Ministério da Saúde, a transmissão ocorre, sobretudo, através do contato sexual sem o uso de camisinha, com uma pessoa que esteja infectada ${ }^{8}$.

De 1980 a 2019, foram registrados 966.058 casos de AIDS no Brasil. Em 2018, 43.941 casos diagnosticados de HIV e 37.161 casos de AIDS, com taxa de mortalidade de 4,4 óbitos por 100 mil habitantes (BRASIL, 2019). Em relação à sífilis adquirida, em 2019, houve o registro de 152.915 casos, sendo 173 óbitos por sífilis congênita. (BRASIL, 2020). De 1999 a 2019, a taxa de detecção de hepatites virais foi de 673.389 casos, sendo 168.036 casos de hepatite A e 253.307 de hepatite B. (BRASIL, 2020).

0 índice de disseminação está ligado a não utilização de camisinha nas relações sexuais e/ou de outras medidas efetivas como, vacinação, higiene pessoal e o não compartilhamento de objetos pessoais. Nesse sentido, ainda que haja um abismo entre a informação e a ação, ela atua como um processo de educação para a proteção. Assim, compreender as formas de contágio, as ações preventivas, os sintomas e o tratamento, possibilita a conscientização dos sujeitos.

Diante desse contexto, viabilizar a educação sexual pode propiciar a ressignificação de condutas e valores voltados ao respeito a si e ao outro, além de conduzir diálogos que promovam reflexão crítica e autonomia acerca da proteção e segurança íntima, pautando-se de informações fundamentadas, e visando a garantia dos direitos das crianças e adolescentes.

\footnotetext{
8 As informações evidenciadas nesse tópico foram retiradas do site do Ministério da Saúde. Disponível em: <http://www.aids.gov.br/pt-br/publico-geral/o-que-sao-ist>. Acesso em: 03 out.2020
} 


\subsubsection{ABUSO InfantiL}

A cultura da dominação arraigada na sociedade suprime os direitos das crianças há tempos, submetendo-as ao controle autocrático. A escritora e teórica feminista, Hooks (2020, p. 110) denota que "a nossa cultura não ama crianças", sendo a violência contra meninas e meninos uma conduta socialmente naturalizada, que permanece negando direitos. $\mathrm{O}$ abuso sexual infantil é um problema extenso que vitimiza milhares de sujeitos anualmente. Segundo, Araújo (2002) é uma ação violenta que dispõe de poder, manipulação e coação.

De acordo com o Anuário Brasileiro de Segurança Pública, em 2018, foram registrados 66.041 casos de violência sexual, 53,8\% das vítimas de estupro tinham até 13 anos, sendo quatro meninas estupradas por hora (BRASIL, 2019). O Ministério da Mulher, da Família e dos Direitos Humanos evidenciou que em 2019, das 159 mil denúncias realizadas pelo Disque 100, 86,8 mil foram de violação dos direitos das crianças e adolescentes, concernindo 17 mil ocorrências de violência sexual, em 73\% dos casos, a violência é cometida na casa da vítima ou do suspeito (BRASIL, 2020), além disso, o abuso sexual intrafamiliar é recorrente. É fundamental evidenciar que a maioria dos casos são subnotificados, não sendo possível retratar sua real dimensão.

Ao discorrer sobre os danos psicológicos causados pelo abuso sexual, nota-se a ausência de estudos específicos, Florentino (2015) buscou referências sobre os impactos da violência doméstica, entendendo que o abuso sexual é uma especificidade de tal violência. Nesse sentido, o autor comenta sobre possíveis manifestações, como: vergonha, medo, culpa, depressão, agressividade, fobia social, transtorno obsessivo-compulsivo, pensamento ilógico, sintomas psicóticos e distúrbios (DAY et al., 2003 apud FLORENTINO, 2015). Continuamente, denota as consequências orgânicas do abuso sexual infantil, explicitando as "lesões físicas gerais; lesões genitais; lesões anais; gestação, doenças sexualmente transmissíveis; disfunções sexuais; hematomas; contusões e fraturas". (FLORENTINO, 2015, p. 141).

0 autor ainda ressalta que o silêncio também compromete a existência das crianças e adolescentes, prevalentemente quando o abuso é intrafamiliar. "Esta vítima busca manter o segredo das situ- 
ações vividas, seja por temor de sofrer sanções e castigos por ambos os genitores, seja por sentir sobre seus ombros a responsabilidade de manter o equilíbrio e integridade da família”. (FLORENTINO, 2015, p. 142). Além disso, a falta de informação faz com que a criança não reconheça o abuso sofrido.

Historicamente instaurou-se um viés proibitivo acerca da sexualidade. Há quem entenda que viabilizá-la compromete a inocência das crianças e que o assunto deve permanecer fora do espaço escolar, sendo assegurado integralmente pela família, no entanto, considerando que na maioria dos casos o abusador pertence ao seio familiar é possível constatar que o ambiente nem sempre é seguro, e pode corroborar para o silenciamento da violência, concomitantemente, há quem pretenda eximir o tema da sociedade a fim de mantê-lo omitido.

A esse respeito, a escassez de dados estatísticos para o monitoramento da violência sexual infantil, de políticas públicas e de programas educacionais voltados à proteção das crianças, assim como a falta de discussões que incentivem a denúncia explicitam a ausência do Estado. Portanto, faz-se urgente romper com a estigmatização do assunto, reconhecendo-o como questão de saúde pública e instituindo medidas educacionais voltadas ao seu enfrentamento, a fim de garantir os direitos das crianças, assim como o artigo 227 da Constituição Federal denomina?

\section{GENÊRo, SEXUALIDADE E EDUCAÇÃo}

\subsection{A ESCOLARIZAÇÃO DAS DESIGUALDADES}

A estrutura sócio-histórica das instituições escolares conduziu os sujeitos a padrões sociais difundidos a partir da sistematização de paradigmas hegemônicos. Considerando que a educação é uma forma

9 De acordo com o Art. 227 É dever da família, da sociedade e do Estado assegurar à criança, ao adolescente e ao jovem, com absoluta prioridade, o direito à vida, à saúde, à alimentação, à educação, ao lazer, à profissionalização, à cultura, à dignidade, ao respeito, à liberdade e à convivência familiar e comunitária, além de colocá-los a salvo de toda forma de negligência, discriminação, exploração, violência, crueldade e opressão. 
de intervenção no mundo, e pode servir tanto para solidificar, quanto para romper os estigmas instalados, as múltiplas concepções disseminadas pela escola interferem na forma como as relações sociais são constituídas (FREIRE, 2019).

Currículos, normas, procedimentos de ensino, teorias, linguagem, materiais didáticos, processo de avaliação são, seguramente, loci das diferenças de gênero, sexualidade, etnia, classe - são constituídos por essas distinções e, ao mesmo tempo, seus produtores. (LOURO, 2014, p. 68, grifo da autora).

A autora ainda elucida a importância de um olhar atento para as práticas cotidianas, visto que elas são responsáveis por influir a construção dos sentidos que circundam as vivências dos meninos e das meninas. As práticas encaminham os sujeitos à formação distintiva, deste modo, as concepções de mundo são compreendidas a partir das relações de poder entre os gêneros e por estereótipos de feminilidade e masculinidade. Moreno (1999) chama atenção para os modelos difundidos pelo androcentrismo, que ao colocar a figura masculina como o "centro do universo", submete as mulheres à secundarização e ao ocultamento. Destarte, as representações, tal como a linguística, são engendradas por significações discriminatórias.

De acordo com Louro (2014), dentre as formas de instauração das desigualdades no espaço escolar, a linguagem é uma das mais expressivas, tendo em vista sua função social. Através dela, a escola é capaz de delimitar as ações dos(as) alunos(as), impulsionar condutas discriminatórias e naturalizar as distinções sociais. Nessa perspectiva, a autora afirma que "a linguagem não apenas expressa relações, poderes, lugares, ela os institui; ela não apenas veicula, mas produz e pretende fixar as diferenças" (p. 69).

Assim como a linguagem, o silenciamento atua como mecanismo para conservar os padrões da heteronormatividade, que quando transgredidos, são desaprovados. Deste modo, as contribuições de Louro denotam que: 
[...] tão ou mais importante do que escutar o que é dito sobre os sujeitos, parece ser perceber o não dito, aquilo que é silenciado - os sujeitos que não são, seja porque não podem ser associados aos atributos desejados, seja porque não podem existir por não poderem ser nomeados. (LOURO, 2014, p. 71, grifos da autora).

Em relação a este tema, Caetano (2013, p. 75) afirma que "é no jogo de apresentações e nas expectativas heteronormativas de gênero que as identidades LGBT são estigmatizadas". Sendo assim, ao não corresponder às normas sociais, em específico, ao modelo heteronormativo, os sujeitos tendem a ser subjugados à negação.

Composta por representações heteronormativas, a escola exime outras corporalidades e passa a legitimar situações de desigualdade. Nesse sentido, a produção (e reprodução) das discriminações instituídas e a falta de intervenção dos professores e das professoras perante atitudes LGBTfóbicas corrobora com a permanência da violência dentro e fora do ambiente escolar que, muitas vezes, acompanha os(as) alunos(as) vitimizados(as) durante toda a trajetória de vida.

Nos livros didáticos, os conteúdos são desenvolvidos por conjunturas hierárquicas de gênero, raça, etnia e classe e não costumam retratar as diversas formas de existir, os diferentes corpos e identidades. Nessa perspectiva, as ilustrações são ferramentas significativas para a manutenção dos padrões androcêntricos e costumam representar papéis sociais baseados nas normas de gênero, delegando à figura feminina funções domésticas, maternas e de cuidados, enquanto atribui à figura masculina atividades esportivas e profissões (MORENO, 1999). Do mesmo modo, a retratação dos arranjos familiares baseados na heteronormatividade anula outras composições de famílias.

Oliveira (2008) elucida que os livros didáticos são suscetíveis à ideologia fortemente arraigada por determinados valores que influenciam a concepção de mundo dos(as) alunos(as). Diante desse contexto, faz-se necessário olhar com criticidade para os conteúdos expostos, a fim de combater as diferenciações concebidas ao longo da história e impulsionar reflexões que viabilizem a diversidade sociocultural.

Moreno (1999) acredita que é preciso abandonar livros que produzam conteúdos sexistas, a fim de romper com a institucionalização 
das discriminações e modificar a forma como as mulheres são retratadas, dando um novo sentido às concepções atribuídas erroneamente.

Além de atuar no desenvolvimento dos saberes, a escola produz identidades pautadas nos modelos hegemônicos (LOURO, 2014). Desta maneira, compreender a sua potência no que tange à escolarização das corporalidades e reconhecer a importância das práticas cotidianas para o rompimento da injunção do sujeito unificado possibilitaria reflexões transgressoras.

Em consonância com essas concepções, Freire (2019) denota que as práticas pedagógicas devem ser baseadas no "respeito à autonomia, à dignidade e à identidade do educando" (p. 61). Além disso, é fundamental ir contra a reprodução das discriminações, uma vez que "a prática preconceituosa de raça, de classe, de gênero ofende a substantividade do ser humano e nega radicalmente a democracia" (FREIRE, 2019, p. 37). Deste modo, a prática consciente deve viabilizar uma educação voltada para o respeito e para repúdio à violência.

Moreno (1999) aponta que embora os estigmas estejam emaranhados na sociedade, a conscientização do corpo docente poderia impulsionar transformações na escola. Para isso, seria necessário que os(as) professores(as) tivessem acesso à formação específica, discussões reflexivas e projetos inovadores capazes de desarraigar o tema do silenciamento.

Em síntese, ainda que o caminho seja árduo, a mudança é possível. Faz-se necessário que, como instituição social, a escola vise assegurar os direitos dos indivíduos, possibilitando que o corpo escolar e os(as) alunos(as) desconstruam estereótipos de gênero e padrões de sexualidade, e assim, contribuam com a ruptura do sistema que segrega, discrimina e vitimiza.

\subsection{PANORAMA histórico}

A escola, construída sob influência dos processos histórico-culturais, é inerente às relações de poder que foram delineadas. As divisões sociais de classe, raça, gênero e sexualidade estão implícitas nessa construção (LOURO, 2014). Então, os assuntos que tangem à sexualidade humana coexistem no cotidiano escolar e ao longo dos 
anos foram encarados através de inúmeras perspectivas, muitas vezes, moralizantes e segregativas.

No Brasil, em 1920, a temática da sexualidade no ambiente escolar foi considerada para o combate a masturbação, a prevenção de IST e o preparo da mulher para exercer os papéis de mãe e esposa (SAYÃO, 1997 apud FERNANDES; LORENZETTI, 2019). Alguns anos depois, em 1928 foi aprovado pelo Congresso Nacional de Educadores o Programa de Educação Sexual nas Escolas, para crianças com idade superior a 11 anos, programa esse que foi concebido através de concepções higienistas que tinham o objetivo de controlar a sexualidade (VIEIRA; MATSUKURA, 2017). E, no período entre 1935 e 1950, houve uma lacuna de retrocessos das iniciativas no campo da educação sexual no Brasil (SAYÃO, 1997 apud FERNANDES; LORENZETTI, 2019).

Valores morais e religiosos já exerciam sua influência sobre a escola e é em 1950 que, mais diretamente, deu-se a intervenção da igreja católica na instituição escolar, culminando na inibição dos assuntos relacionados à sexualidade e, assim, a sexualidade foi reprimida até a década seguinte (SAYÃO, 1997 apud FERNANDES; LORENZETTI, 2019). Já no início da década de 60, houve a movimentação de grupos que, na busca por direitos civis, trouxeram reinvindicações étnico-raciais, feministas e LGBT's, o que refletiu em novos discursos e reflexões a respeito da instituição escolar. Nesse momento foi retomado, através de uma visão mais crítica, os debates e propostas sobre a educação sexual (CÉSAR, 2009).

No início da ditadura militar, em 1965, os assuntos de gênero e sexualidade foram suprimidos e até proibidos de se integrarem aos conteúdos escolares e, mesmo assim, cresceu o interesse de educadoras(es) pela educação sexual (CÉSAR, 2009). É nesse mesmo período em 1968 que, no Rio de Janeiro, foi apresentado pela deputada Júlia Steimburck um projeto de lei voltado à implantação obrigatória da educação sexual nas escolas do país (FERNANDES; LORENZETTI, 2019).

Ainda na luta pela democratização, a educação sexual voltou a ser discutida através de uma perspectiva feminista, que se pautava na liberdade dos sujeitos, entretanto essa narrativa não se fortaleceu e a educação sexual foi concebida, em 1980, como campo inerente da saú- 
de e da biologia (CÉSAR, 2009). Na década de 80, com uma abertura política, alguns padrões sociais conservadores e preconceituosos começaram a ser questionados, o que influenciou em novos comportamentos e considerações no campo da sexualidade (FERNANDES; LORENZETTI, 2019). Por outro lado, nesse mesmo período, aconteceu o avanço da epidemia de HIV/AIDS no Brasil, o que também, posteriormente, teve sua influência no campo da educação sexual.

Novos debates surgiram na década de 90, então os discursos a respeito da prevenção de IST e da gravidez na adolescência se tornaram predominantes, dando esse caráter excepcionalmente preventivo para a discussão da sexualidade nas escolas (CESAR, 2009). Em 1996, foi proposto pelo governo brasileiro os Parâmetros Curriculares Nacionais (PCN) com a intencionalidade de ser um documento que assegurasse acesso a saberes fundamentais aos sujeitos para o pleno exercício da cidadania. Nele, os saberes pertinentes à sexualidade são considerados inerentes à vida e, por isso, precisam ser encarados de maneira responsável, democrática e respeitando às múltiplas formas de existir (FERNANDES; LORENZETTI, 2019).

Em 2011, as pautas de gênero e sexualidade voltaram ao centro do debate no momento em que o programa Escola Sem Homofobia (ESH) foi apresentado como alternativa para introduzir conceitos que visibilizavam grupos marginalizados no ambiente educacional, como a população LGBT, e refletiam criticamente sobre identidades e vivências de gênero. Entretanto, desde o lançamento do programa Brasil Sem Homofobia, em 2004, voltado para o combate à discriminação e violência da comunidade LGBT, setores ultraconservadores se articulavam no Congresso Nacional para que os materiais do programa não fossem aprovados na ocasião e o mesmo fizeram com o ESH, resultando no veto da presidenta Dilma Rousseff (SILVA, 2020).

A mobilização para que o programa não fosse aprovado se fortaleceu através de discursos expressivamente machistas, homofóbicos e da disseminação de informações distorcidas sobre os conteúdos que o envolviam, sendo pejorativamente rebatizado de "Kit Gay", como ficou popularmente conhecido (SILVA, 2020).

Essa oposição novamente se mobilizou quando o Plano Nacional da Educação (PNE) documento que contém as diretrizes para a educaRevista Páginas de Filosofia, v. 10, n. 1, p. 137-171, jan.-jun. 2021 
ção brasileira de 2014 a 2024 - passou a ser discutido no Congresso Nacional. Dessa vez, grupos conservadores se valeram do argumento da "ideologia de gênero" para deslegitimar as pautas de gênero e sexualidade contidas no texto base do projeto original, termo que foi amplamente disseminado no Brasil. A retórica da "ideologia de gênero" começou a ser usada por indivíduos atuantes da bancada do boi, da bala e da bíblia para se referirem negativamente aos estudos de gênero, sexualidade e às reinvindicações da população LGBT (SILVA, 2020).

Com essas articulações pautadas em ideias distorcidas, os assuntos de igualdade de gênero e orientação sexual foram omitidos ou até mesmo retirados do texto final do PNE e, junto a isso, diversos projetos políticos foram propostos com a intenção de reprimir por completo qualquer menção a esses temas dentro da sala de aula (SILVA, 2020).

Até que em 2017, na construção da Base Nacional Comum Curricular (BNCC), documento com as atuais referências para a elaboração dos currículos da educação básica no Brasil, os assuntos sobre gênero, sexualidade e promoção de direitos da população LGBT foram completamente excluídos. E, sem a participação popular, a BNCC foi aprovada no Ministério da Educação (SILVA, 2020).

Atualmente, as possíveis temáticas curriculares envolvendo gênero e sexualidade, seguem um caminho de resistência e debate, devido a ataques de setores conservadores, em escala nacional, estadual e municipal. Pautados ainda em argumentos religiosos e visões distorcidas sobre o assunto, na defesa de uma suposta moralidade.

\subsection{O OCULTAMENTO DE GÊNERO E SEXUALIDADE NA BNCC}

Os mecanismos que envolvem as instituições escolares são engendrados por significações instituídas com base nas relações de poder historicamente concebidas. Uma das dimensões dessa realidade são as consequências do que é ensinado e aprendido nas escolas ou do que sequer é mencionado.

Considerando a funcionalidade do currículo no que tange os conhecimentos escolares, Moreira e Candau (2007, p. 28) denotam que "o currículo, representa, assim, um conjunto de práticas que propiciam a produção, a circulação e o consumo de significados no espaço social 
e que contribuem, intensamente, para a construção de identidades sociais e culturais". Nesse sentido, rodeado de representações constituídas socialmente por perspectivas hegemônicas, o currículo passa a consolidar relações de desigualdade.

De acordo com Silva, a definição dos conteúdos expostos no currículo costuma elevar um grupo enquanto marginaliza outros, sendo capaz de corroborar com a reprodução das divisões sociais (SILVA, 1996 apud LOURO, 2014). Do mesmo modo, o currículo determina quais são os conteúdos a serem ocultados.

Nessa hierarquia, legitimam-se saberes socialmente reconhecidos e estigmam-se saberes populares. Nessa hierarquia, silenciam as vozes de muitos indivíduos e grupos sociais e classificam-se seus saberes como indignos de entrarem na sala de aula e de serem ensinados e aprendidos. Nessa hierarquia, reforçam-se relações de poder favoráveis à manutenção das desigualdades e das diferenças que caracterizam nossa estrutura social. (MOREIRA; CANDAU, 2007, p. 25).

Reconhecer a responsabilidade do currículo como ferramenta de conservação das distinções, compreende analisar a forma como os sentidos são dispostos ou silenciados. Assim, faz-se necessário entender, a partir da perspectiva dos PCN até à contemporaneidade com a implementação da BNCC, como Gênero e Sexualidade é tratado nos currículos.

Percebido desde a década de 1920, ainda que atribuído à dimensão higienista (CÉSAR, 2009), o tema de sexualidade já era constituinte das intervenções educacionais. A partir de 1980, com o avanço dos casos de HIV/AIDS e o alto índice de gravidez na adolescência, a escola passou a incorporar discussões mais amplas provenientes dessas problemáticas (BRASIL, 1997).

A promulgação dos PCN, no ano de 1997, promoveu novas concepções em relação às diretrizes educacionais, como é o caso da abordagem descrita como "orientação sexual" nos temas transversais. Embora, estivesse inicialmente voltado à prevenção de IST e da gravidez precoce, o que mantém "a sujeição ou subordinação da temática de gênero ao trinômio corpo/saúde/doença” (VIANNA; UNBEHAUM, 2004, p. 100), a introdução ao tema possibilitou que discussões fundamentais atra- 
vessassem a sistematização dos conteúdos e foi tida como um avanço no que tange às políticas públicas de educação.

Assim, os PCN (BRASIL, 1997, p. 87) reconhecem a importância "de se abordar a sexualidade da criança e do adolescente não somente no que tange aos aspectos biológicos, mas também e principalmente, aos aspectos sociais, culturais, políticos, econômicos e psíquicos dessa sexualidade". E, a partir disso, buscam compreender a maneira como essas questões afetam a subjetividade dos sujeitos.

No que diz respeito às relações de gênero, Vianna e Unbehaum (2004) denotam que os PCN as evidenciam, considerando sua importância para o desenvolvimento da identidade dos indivíduos, com ênfase às diferenças constituídas em detrimento do sexo. No entanto, relevam que "os PCN, porém, não estão impregnados de uma perspectiva de gênero, a qual, a nosso ver, deveria perpassar todas as áreas do conhecimento e não estar atrelada estritamente à Orientação Sexual” (p. 101).

Ainda que haja problemáticas em relação à forma como os conteúdos são apresentados, a inserção das questões de gênero e sexualidade caminha em direção à possibilidade de transformação social. Nesse sentido, os PCN visam impulsionar a reflexão crítica, a conscientização em relação à prevenção e a minimização de discriminações (BRASIL, 1997). Contudo, sua não obrigatoriedade indica que tais conteúdos poderão não ser abordados.

Homologada em 2017, a BNCC foi caracterizada como documento normativo e obrigatório, apresentando conteúdos metodológicos a serem seguidos em nível nacional. Em contrapartida aos avanços constatados com os PCN, termos como "orientação sexual" e "identidade de gênero" foram ocultados. Nesse sentido, a professora Margareth Rago ${ }^{10}$ denota que a omissão desses termos representa um retrocesso significativo no que tange às questões de gênero e sexualidade, e afirma que o posicionamento dos grupos religiosos fomenta a tentativa de anular formas de sexualidade que transgridam o padrão heteronormativo (ALVES FILHO, 2017).

10 Professora do Departamento de História do Instituto de Filosofia e Ciências Humanas (IFCH) da Unicamp.

Revista Páginas de Filosofia, v. 10, n. 1, p.137-171, jan.-jun. 2021 
Silva, Brancaleoni e Oliveira (2019) destacam que a abordagem da sexualidade presente na BNCC é reputada no campo de Ciências, numa perspectiva de prevenção e associada à face biológica, portanto, as concepções ligadas ao âmbito higienista foram mantidas.

Assim, as contrariedades pertencentes às condutas, valores, sentidos e tabus foram omitidas. Ao suprimir reflexões acerca de outras dimensões referentes a gênero e sexualidade, tal como a violência, mantém-se os estigmas que solidificam as discriminações reproduzidas e produzidas pela instituição escolar. Diante desse contexto, a antropóloga e pesquisadora Regina Facchini afirma ${ }^{11}$ que inviabilizar essas questões na BNCC é desconsiderar os direitos das crianças e dos(as) adolescentes, visto que estereótipos de feminilidade e masculinidade causam danos a todos os sujeitos, independentemente da orientação sexual (ALVES FILHO, 2017).

Em relação aos direitos humanos, a BNCC apresenta a diversidade numa perspectiva de respeito às diferenças e de combate às discriminações, mas deixa implícito a que se refere. Assim, "sua utilização genérica poderá resultar em compreensões simplistas sobre o respeito à diversidade", impedindo que o conteúdo de gênero e sexualidade seja abordado, principalmente, considerando as dificuldades que os professores e as professoras têm em lidar com o tema devido à ausência de conteúdos formativos, por exemplo, no curso de licenciatura (SILVA; BRANCALEONI; OLIVEIRA, 2019, p. 1549).

Vianna e Unbehaum (2004) afirmam que a não menção ou a superficialidade com que as políticas públicas tratam as questões de gênero corrobora com o ocultamento do tema na escola. Nesse sentido, ao passo que o currículo desvanece essas compreensões, as possibilidades de mudança são interrompidas.

Considerando o vasto histórico de discriminação, preconceito e violência de gênero no Brasil, é urgente a ação de políticas públicas que incorporem tais discussões no currículo nacional a fim de viabilizá-las como parte intrínseca do processo de formação humana.-

${ }_{11}$ Pesquisadora do Núcleo de Estudos de Gênero (Pagu) da Unicamp. 


\section{GENÊRO E SEXUALIDAdE NA ESCOLA: UM DIÁlOGO NECESSÁRIO}

\subsection{RESPONSABILIDADE SOCIAL DA ESCOLA}

A instituição escolar coexiste juntamente aos contextos sociais e culturais a qual ela está inserida e, em sua historicidade, foi e é influenciada pelas relações de poder, bem como interfere nessas relações. Desse modo, a escola como instituição que existe e age sobre uma complexa engrenagem, precisa admitir sua responsabilidade social, através de um olhar sensível para as relações humanas.

A esse respeito, Louro (p. 89, grifo da autora, ano) elucida que "a escola não apenas transmite conhecimentos, nem mesmo apenas os produz, mas ela também fabrica sujeitos, produz identidades". Nesse sentido, é importante reconhecer seu papel na formação social dos indivíduos e olhar para a instituição como um espaço político passivo de mudanças, assim, ao nos depararmos com as inquietações e inconformidades que permeiam o ato educacional podemos assumir uma posição de intervenção perante as desigualdades (LOURO, 2014).

Considerando a relevância social da instituição escolar, é necessário que ela viabilize discussões acerca dos assuntos de gênero e sexualidade, inserindo-os em seu currículo formativo com um olhar atento às demandas dos(as) alunos(as), pois as pautas envolvidas nessas temáticas dizem respeito às suas próprias vidas.

Algumas problemáticas implícitas nas construções da sexualidade, como as relações com o outro, o prazer, o autocuidado e os limites do corpo, devem ser argumentados na sala de aula de maneira criteriosa, pois são assuntos que fazem parte do cotidiano de todos os sujeitos que estão construindo suas identidades. A exemplo, temos a urgência de combater a violência sexual e de proteger crianças de possíveis abusos (SANTOS, 2018).

Há também violências que partem das diferenciações que foram socialmente construídas sobre as identidades de gênero e sobre os comportamentos esperados de meninos e meninas. Essas diferenciações estando implícitas no fazer educacional, torna a escola um lugar de enorme relevância para romper com paradigmas sexistas e discriminatórios (MORENO,1999). 
Assim, como o respeito às diversidades existentes é um assunto pertinente a toda comunidade escolar, jovens LGBT's precisam enxergar de maneira positiva e natural suas maneiras de expressão, seus sentimentos e seus desejos, sendo também de responsabilidade da escola criar esse ambiente acolhedor (LOURO, 2014).

Por este viés, Louro (2014) ressalta que é fundamental adotarmos uma visão crítica acerca dos elementos tidos como naturais nas práticas cotidianas, visto que a naturalização impede a reflexão. A linguagem, os livros didáticos, os métodos de ensino e o currículo são campos engendrados pelas relações desiguais de gênero e sexualidade, mas ao considerarmos que essas relações foram construídas socialmente, há possibilidade de subversão.

É importante considerar as significações que permeiam a figura do(a) educador(a), o qual tem absoluto efeito sobre o aluno e sobre a realidade que o cerca (HOOKS, 2017). Nessa perspectiva, observar, conhecer e questionar as desigualdades implica na necessidade da percepção sensível voltada à informação, ao conhecimento, ao entusiasmo e à determinação política (LOURO, 2014).

Assim, ainda que haja oposições a confrontar, ser professor(a) exige reconhecer que o posicionamento contra as discriminações é um dever que não pode ser dissociado da prática pedagógica. Portanto, o "respeito à autonomia e à dignidade de cada um é um imperativo ético e não um favor que podemos ou não conceder uns aos outros" (FREIRE, 2019, p. 58). Nesse contexto, Hooks (2017) retoma que mediatizar discussões sobre as diferentes corporalidades em sala de aula desafia o estabelecimento do poder institucionalizado:

Temos de voltar a um estado de presença no corpo para desconstruir o modo como o poder tradicionalmente se orquestrou na sala de aula, negando subjetividade a alguns grupos e facultando-a outros. Reconhecendo a subjetividade e os limites da identidade, rompemos essa objetificação tão necessária numa cultura de dominação. (HOOKS, 2017, p. 186).

Para a autora as ideologias hegemônicas que cercam o ambiente escolar alteraram o sentido da educação tão fortemente que ela deixou de ser uma prática de liberdade, assim, a abordagem multiculturalista 
passa a viabilizar novas possibilidades de ensino, voltadas à diversidade e à inclusão.

Quando nós, como educadores, deixamos que a nossa pedagogia seja radicalmente transformada pelo reconhecimento da multiculturalidade do mundo, podemos dar aos alunos a educação que eles desejam e merecem. Podemos ensinar de um jeito que transforma a consciência, criando um clima de livre expressão que é a essência de uma educação em artes liberais verdadeiramente libertadora. (HOOKS, 2017, p. 63).

Desse modo, a educação libertadora pode atuar como um meio de ressignificação das práticas, de encontro à diversidade sociocultural. Para isso, os(as) professores(as) precisam ter consciência do pensar e agir pedagógico, dada a responsabilidade da escola no rompimento da violência institucionalizada e da segregação social.

\subsection{O PODER TRANSFORMADOR DA EDUCAÇÃO}

As vivências de gênero e sexualidade foram historicamente atravessadas por conflitos advindos das relações de poder, as quais trataram de normatizar os sujeitos na tentativa de controle dos seus corpos e marginalizar todos que de alguma forma transgridem os padrões sociais. Tais distinções sociais geram inúmeras violências e problemáticas, dentro e fora das instituições educacionais e, com isso, a escola não deve se eximir do seu potencial de transformação na vida das pessoas que, de alguma forma, tiveram suas existências negligenciadas. Sobre isso, Paulo Freire afirma:

Outro saber que não posso duvidar um momento sequer na minha prática educativo-crítica é o de que, como experiência especificamente humana, a educação é uma forma de intervenção no mundo. Intervenção que, além dos conhecimentos dos conteúdos bem ou mal ensinados e/ou aprendidos, implica tanto o esforço de reprodução da ideologia dominante quando o seu desmascaramento. (FREIRE, 2019, p. 96, grifos do autor).

Ainda de acordo com as ideias de Freire (2019), o fazer educacional exige a rejeição das desigualdades e atitudes discriminatórias, pois essas ofendem a qualidade da democracia. Sendo assim, afirmamos 
que a educação tem um compromisso com a promoção de práticas inclusivas, que valorize as multiplicidades culturais, legitime as diversas expressões de gênero e sexualidade, combata cotidianamente a violência e preze pela constante transformação social.

Esse processo de transformação consiste na percepção crítica da realidade, em questionar valores e crenças limitantes, no olhar humano para o fazer pedagógico e na construção colaborativa de uma educação comprometida com a liberdade do ser. Além disso, é necessário o reconhecimento, por uma perspectiva de alteridade, que o outro é um universo singular o qual nunca poderá ser compreendido por completo e, por isso, qualquer relação só será possível por meio do respeito e do diálogo (MATOS, 2016).

Ao reconhecermos a potencialidade da prática educativa, não podemos nos pautar em uma ideia simplista e ingênua de que a educação pode pôr fim às relações de poder e desigualdades resultantes delas (LOURO, 2014), mas sim na ideia de que, através de iniciativas inclusivas, seja possível tocar os indivíduos, de forma que se sintam pertencentes aos espaços que ocupam e motivados a buscarem a transformação. Nas palavras de HOOKS (2017), "fazer da sala de aula um contexto democrático onde todos sintam a responsabilidade de contribuir é um objetivo central da pedagogia transformadora" (p. 56).

E, ainda, sobre o sentimento de pertencimento que a escola pode gerar a todos os indivíduos e principalmente, àqueles a qual esse sentimento ainda é negado:

0 fato de me perceber no mundo, com o mundo e com os outros me põe numa posição em face do mundo que não é de quem nada tem a ver com ele. Afinal, minha presença no mundo não é a de quem a ele se adapta, mas a de quem nele se insere. É a posição de quem luta para não ser apenas objeto, mas sujeito também da história. (FREIRE, 2019, p. 53, grifo do autor).

Portanto, é necessário que o fazer educacional seja caminho para o reconhecimento da singularidade de cada indivíduo, para a legitimação de cada existência e para a constante defesa da integridade das pessoas e seus direitos, formando sujeitos críticos, autônomos e atuantes em suas trajetórias de vida.

Revista Páginas de Filosofia, v. 10, n. 1, p. 137-171, jan.-jun. 2021 


\section{CONSIDERAÇõES FINAIS}

Mesmo com um significativo histórico de problemáticas e violências, no Brasil, decorrentes dos paradigmas de gênero e sexualidade, há a omissão da relevância social de abordar, por meio do currículo, esses assuntos no ambiente escolar. Ainda que faça parte inteiramente da essência do ser humano, a temática permanece sendo socialmente negada, desse modo, esta pesquisa evidenciou a importância de viabilizá-la nas escolas, uma vez que a identidade de meninas e meninos é, por ela, atravessada.

Compreender a rejeição em torno do assunto foi possível, neste estudo, através do resgate da constituição sócio-histórica de gênero e sexualidade. Nos deparamos com uma sociedade construída por meio das relações de poder e que, com isso, criou divisões desiguais de raça, classe, etnia, gênero e sexualidade, gerando um padrão androcêntrico, binário e heteronormativo de existência, que teve por consequência, no âmbito nacional, a violência de gênero, a LGBTfobia e diversas outras problemáticas envolvendo a sexualidade. Sabemos, também, que essas circunstâncias são atravessadas e, muitas vezes, agravadas pelas demais condições de desigualdades étnico-raciais, regionais e econômicas.

Além disso, crianças e jovens, no contexto educacional, constituem as diversidades culturais e humanas, então tratando da responsabilidade da escola na formação dos sujeitos, evidenciamos que se ela pode reproduzir as desigualdades em seus discursos, linguagens e currículos, ela pode, em contrapartida, transgredir os padrões hegemônicos.

Confirmamos, assim, a hipótese de que a construção histórica de gênero e sexualidade naturalizou paradigmas discriminatórios. E que, mais recentemente, esses paradigmas foram fomentados por setores conservadores que se articularam para que as questões de gênero e sexualidade não fossem inseridas nas salas de aula, processo que resultou na completa omissão da temática na aprovação da BNCC.

Essa pesquisa pôde discernir o panorama histórico da coexistência de gênero, sexualidade e educação, bem como suas implicações na construção do currículo escolar. Procurando romper com visões estigmatizadoras sobre o tema, mostramos que não se trata de conceitos inapropriados para crianças e jovens, mas sim de conteúdos que estão 
diretamente ligados com a construção de suas identidades e que são efetivamente importantes ao serem abordados de maneira organizada, crítica e responsável, fazendo da escola lugar de práticas transformadoras.

Diante da necessidade de desobedecer a paradigmas discriminatórios e excludentes, gênero e sexualidade, junto aos assuntos que os permeiam, devem ser considerados, sobretudo porque a instituição escolar é atuante no processo de desenvolvimento de sujeitos diversos em suas corporalidades e representações. Admitindo o compromisso de uma educação que oportunize a transformação dos sujeitos e suas maneiras de existir no mundo, por meio do diálogo, do respeito e da alteridade, fazendo com o que os(as) alunos(as) se sintam legitimados(as) e pertencentes aos espaços que ocupam.

Salientamos a importância de que o tema siga sendo um autêntico objeto de estudo e, para além disso, que seja integralmente agregado ao currículo formativo para que a prática seja efetivamente proporcionada, através de uma educação crítica e humana.

\section{REFERÊNCIAS}

ALTMANN, H. Diversidade sexual e educação: desafios para a formação docente. Sexualidad, Salud y Sociedad. REVISTA LATINOAMERICANA. Rio de Janeiro, n. 13, p. 69-82, abr., 2013. Scielo Brasil.

ALVES FILHO, M. Especialistas veem retrocesso em supressão do termo 'orientação sexual' da base curricular. Jornal da Unicamp, 2017. Disponível em: https://www.unicamp.br/unicamp/index.php/ju/noticias/2017/04/07/especialistas-veem-retrocesso-em-supressao-do-termo-orientacao-sexual-da. Acesso em: 22 out. 2020.

ARAÚJO, M. F. Violência e abuso sexual na família. Psicologia em Estudo. Maringá, v. 7, n. 2, p. 3-11, jul./dez. 2002. Scielo Brasil.

ASSOCIAÇÃO BRASILEIRA DE LÉSBICAS, GAYS, BISSEXUAIS, TRAVESTIS E TRANSEXUAIS. Secretaria de Educação. Pesquisa Nacional sobre o Ambiente Educacional no Brasil 2015: as experiências de adolescentes e jovens lésbicas, gays, bissexuais, travestis e transexuais em nossos ambientes educacionais. Curitiba: ABGLT, 2016.

ASSOCIAÇÃO NACIONAL DE TRAVESTIS E TRANSEXUAIS. Assassinatos contra travestis e transexuais brasileiras em 2020. [S. l.]: ANTRA, 2020.

BRASIL. Constituição Federal do Brasil. 1988. Disponível em: < https://www.senado.leg. br/atividade/const/con1988/CON1988 05.10.1988/art_227 asp>. Acesso em: 13 set. 2020. 
BRASIL. Fórum Brasileiro de Segurança Pública. Anuário Brasileiro de Segurança Pública. [S. I.] 2019. 218 p. Disponível em: https://forumseguranca.org.br/wp-content/ uploads/2019/10/Anuario-2019-FINAL_21.10.19.pdf. Acesso em: 9 ago. 2020.

BRASIL. Infecções Sexualmente Transmissíveis. Departamento de Doenças de Condições Crônicas e Infecções Sexualmente Transmissíveis. Disponível em: http://www. aids.gov.br/pt-br/publico-geral/o-que-sao-ist. Acesso em: 3 set. 2020

BRASIL. Ministério da Saúde. Secretaria de Vigilância em Saúde. Boletim Epidemiológico Hepatites Virais. Brasília: Ministério da Saúde, 2020. 79 p.

BRASIL. Ministério da Saúde. Secretaria de Vigilância em Saúde. Boletim Epidemiológico HIV/ aids. Brasília: Ministério da Saúde, 2019.70 p.

BRASIL. Ministério da Saúde. Secretaria de Vigilância em Saúde. Boletim Epidemiológico Sífilis. Brasília: Ministério da Saúde, 2020. 42 p.

BRASIL. Ministério divulga dados de violência sexual contra crianças e adolescentes. Ministério da Mulher, da Família e dos Direitos Humanos. 2020. Disponível em: https://www.gov.br/mdh/pt-br/assuntos/noticias/2020-2/maio/ministerio-divulga-dados-de-violencia-sexual-contra-criancas-e-adolescentes. Acesso em: 5 set. 2020

BRASIL. Secretaria de Educação Fundamental. Parâmetros curriculares nacionais: introdução aos parâmetros curriculares nacionais. Secretaria de Educação Fundamental. Brasília: MEC, 1997, 126 p.

BENITO, E de. OMS retira a transexualidade da lista de doenças mentais. El País, $(S$. I.), 2018. Disponível em: https://brasil.elpais.com/brasil/2018/06/18/internacional/1529346704_000097.html. Acesso em: 11 ago. 2020.

CAETANO, M. Movimentos curriculares e a construção da heteronormatividade. In: Alexsandro Rodrigues; Maria Aparecida Santos Corrêa Barreto, (Orgs). Currículos, gêneros e sexualidades: experiências misturadas e compartilhadas. Espirito Santo: Edufes, 2015. 63-82 p.

CARVALHO, M. C.; SIVORI, H. F. Ensino religioso, gênero e sexualidade na política educacional brasileira. Cadernos Pagu. Campinas, n.50, dez., 2017. Scielo Brasil.

CÉSAR, M. R. A. Gênero, sexualidade e educação: notas para uma "Epistemologia". Educar em Revista. Curitiba, n. 35, p. 37-51, 2009. Scielo Brasil.

CHILDHOOD BRASIL. Conheça mais sobre a Childhood Brasil. Quem somos. [1999?]. Disponível em: https://www.childhood.org.br/quem-somos. Acesso em: 10 set. 2020

CHILDHOOD BRASIL. Educação sexual para a prevenção do abuso sexual de crianças e adolescentes. 2019. Disponível em: https://www.childhood.org.br/educacao-sexual-para-a-prevencao-do-abuso-sexual-de-criancas-e-adolescentes\#: :text=A\%20 educa $\%$ C $3 \%$ A7\%C $3 \%$ A30 $\% 20$ sexual $\% 20 \%$ C 3\%A $\% 20$ uma,sexual $\% 20$ contra $\% 20$

Revista Páginas de Filosofia, v. 10, n. 1, p.137-171, jan.-jun. 2021 
crian $\%$ C $3 \%$ A7as $\% 20 \mathrm{e} \% 20$ adolescentes.\&text=0\%20di $\%$ C3\%A $1 \log _{0} \% 20$ sobre $\% 20$ temas $\% 20$ que,emocional $\% 20 \mathrm{de} \% 20$ crian $\% \mathrm{C} 3 \% \mathrm{~A} 7 \mathrm{as} \% 20 \mathrm{e} \% 20$ adolescentes.. Acesso em: 16 set. 2020

DIAS, A. C. G.; TEIXEIRA, M. A. P. Gravidez na adolescência: um olhar sobre um fenômeno complexo. Paidéia. Ribeirão Preto, v.20, n.45, p. 123-131, jan./abr., 2010. Scielo Brasil.

FARIA, F. Casamento gay não é lei, mas é direito garantido pela Justiça; entenda. Folha de São Paulo, 2018. Disponível em: https://www1.folha.uol.com.br/cotidiano/2018/11/casamento-gay-nao-e-lei-mas-e-direito-garantido-pela-justica-entenda. shtml. Acesso em: 13 ago. 2020.

FERNANDES, F.; LORENZETTI, L. A educação sexual nos anos iniciais: um estudo a partir de dissertações e teses. Revista Brasileira de Ensino de Ciência e Tecnologia. Ponta grossa, v. 12, n. 1, p. 507-522, jan./abr. 2019

FLORENTINO, B. R. B. As possíveis consequências do abuso sexual praticado contra crianças e adolescentes. Fractal: Revista de Psicologia. Minas Gerais, v. 27, n. 2, p. 139-144, maio./ago. 2015. Scielo Brasil.

FREIRE, L.; CARDINALI, D. O ódio atrás das grades: da construção social da discriminação por orientação sexual à criminalização da homofobia. Sexualidade, saúde e sociedade. Rio de Janeiro, n. 12, p. 37-63, dez. 2012. Scielo Brasil.

FREIRE, P. Pedagogia da autonomia: saberes necessários à prática educativa. 25. ed. São Paulo: Paz e Terra, 2019. 143 p.

GRUPO GAY DA BAHIA. O que é o GGB (nossa história). [1980?]. Disponível em: https://grupogaydabahia.com.br/about/o-que-e-o-ggb-nossa-historia/. Acesso em: 18 ago. 2020.

HOOKS, B. Ensinando a transgredir: a educação como prática de liberdade. Tradução: Marcelo Brandão Cipolla. 2. ed. São Paulo: WMF Martins Fontes, 2017. 283 p.

HOOKS, B. 0 feminismo é para todo mundo: políticas arrebatadoras. Tradução: Bhuvi Libanio. 10. ed. Rio de Janeiro: Rosa dos Tempos, 2020. 176 p.

IBGE. Estatísticas de Gênero: indicadores sociais das mulheres no Brasil. Rio de Janeiro, 2018. Disponível em: https://biblioteca.ibge.gov.br/visualizacao/livros/ liv101551 informativo.pdf. Acesso em: 15 ago. 2020

JESUS, J. G. Orientações sobre identidade de gênero: conceitos e termos. 2 ed. Brasília: Jaqueline Gomes de Jesus, 2012. 41 p.

JOVENS AGENTES PELA IGUALDADE DE GÊNERO. Ação educativa. Por que discutir gênero na escola?..São Paulo: JADIG, 2016.

Revista Páginas de Filosofia, v. 10, n. 1, p. 137-171, jan.-jun. 2021 
LINS, B. A.; MACHADO, B. F.; ESCOURA, M. Diferentes, não desiguais: a questão de gênero na escola. 1. ed. São Paulo: Reviravolta, 2016. 144 p.

LOURO, G. L. Gênero, sexualidade e educação: uma perspectiva pós-estruturalista. 16. ed. Rio de Janeiro: Vozes, 2014. 184 p.

MAIA, D. Há 30 anos, OMS tirou homossexualidade de catálogo de distúrbios. Folha de São Paulo, 2020. Disponível em: https://www1.folha.uol.com.br/cotidiano/2020/05/ ha-30-anos-oms-tirou-homossexualidade-de-catalogo-de-disturbios.shtml. Acesso em: 17 ago. 2020

MATOS, H. A. Por uma pedagógica do absurdo. ResearchGate. São Paulo, out. 2016. Disponível em: file:///C:/Users/Windows/Downloads/POR_UMA_PEDAGOGICA_DO_ABSURD0.pdf. Acesso em: 11 nov. 2020

MINAYO, M. C. S. et al. Pesquisa Social: teoria, método e criatividade. In: Maria Cecília de Sousa Minayo, (Org)18 ed. Petrópolis: Vozes, 2001. 80 p.

MOREIRA, A. F. B.; CANDAU, V. M. Indagações sobre currículo: currículo, conhecimento e cultura. Brasília: Ministério da Educação, Secretaria de Educação Básica, p. 01-48, 2007. Disponível em: http://portal.mec.gov.br/seb/arquivos/pdf/Ensfund/ indag3.pdf. Acesso em: 21 set. 2020.

MORENO, M. Como se ensina a ser menina: o sexismo na escola. Tradução: Ana Venite Fuzatto. São Paulo: Moderna, 1999. 80 p.

OLIVEIRA, M. W. Gravidez na adolescência: Dimensões do problema. Cafajeste. CEDES. Campinas, v. 19, n. 45, p. 48-70, jul. 1998. Scielo Brasil.

OLIVEIRA, S. Texto visual, estereótipos de gênero e o livro didático de língua estrangeira. Trabalhos em Linguística Aplicada. Campinas, v. 47, n. 1, p. 91-117, jan./jun. 2008. Scielo Brasil.

OLIVEIRA, T. Prevenção de gravidez na adolescência é tema de campanha nacional. Ministério da Saúde, fev., 2020. Disponível em: https://www.gov.br/saude/pt-br/assuntos/noticias/prevencao-de-gravidez-na-adolescencia-e-tema-de-campanha-nacional. Acesso em: 11 set. 2020.

POMPEU, A. STF autoriza pessoa trans a mudar nome mesmo sem cirurgia ou decisão judicial: ADI 4.275 e RE 670.422. Revista Consultor Jurídico, 2018. Disponível em: https://www.conjur.com.br/2018-mar-01/stf-autoriza-trans-mudar-nome-cirurgia-ou-decisao-judicial. Acesso em: 13 ago. 2020

SANTIAGO, D. As interseccionalidades necessárias à questão do enfrentamento da violência contra mulher. In: Fórum Brasileiro de Segurança Pública e Data Folha. A vitimização de mulheres no Brasil. [S. I.] 2019. 50 p. Disponível em: https://forumseguranca.org.br/wp-content/uploads/2019/02/relatorio-pesquisa-2019-v6.pdf. Acesso em: 13 ago. 2020.

Revista Páginas de Filosofia, v. 10, n. 1, p.137-171, jan.-jun. 2021 
SANTOS, G. L. Educação na expansão PAIR/MG. In: Edite da Penha Cunha, Eduardo Moreira da Silva e Maria Amélia de Castro Giovanetti, orgs. Enfrentamento à violência sexual infanto-juvenil: expansão do PAIR. Minas Gerais: Editora UFMG, 2008. p. 275-293. Disponível em: <http://pair.ledes.net/gestor/titan. php?target $=$ openFile \&fileId $=214>$ _Acesso em: 23 out. 2020

SILVA, C. S. F.; BRANCALEONI, A. P. L; OLIVEIRA, R. R. Base Nacional Comum Curricular e diversidade sexual e de gênero: (des) caracterizações. Revista Ibero-Americana de Estudos em Educação. Araraquara, v. 14, n. esp. 2, p. 1538-1555, jul. 2019. Disponível em: <https://periodicos.fclar.unesp.br/iberoamericana/article/view/12051/8347>. Acesso em: 20 set. 2020.

SILVA, D. S. N.; MIRANDA, M. H. G.; SANTOS, M. C. G. Homofobia e interseccionalidade: sentidos condensados a partir de uma pesquisa bibliográfica. Revista Interritórios.

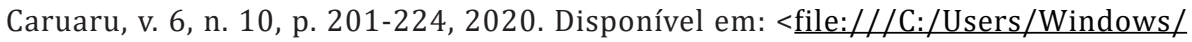
Downloads/ref\%201.pdf>. Acesso em: 15 ago. 2020

SILVA, L. S. S. Pânico moral e as questões de gênero e sexualidade na BNCC. História, histórias. Bahia, v. 8, n. 16, p. 138-162, jul./dez. 2020. Disponível em: <https://periodicos.unb.br/index.php/hh/article/view/31928/27779> Acesso em: 12 set. 2020.

SOBRAL, H. S.; SILVA, M. L. V.; FERNANDES, S. C. S. Homofobia: o que a psicologia brasileira tem a dizer? Artigo de revisão. Revista CES Psicologia. Alagoas, v. 12, n. 3, p. 20-34, set./out. 2019. CES Psicologia.

TONELI, M. J. F. Sexualidade, gênero e gerações: continuando o debate. In: JACÓ-VILELA, A. M., e SATO, L., (Orgs) Diálogos em psicologia social. Rio de Janeiro: Centro Edelstein de Pesquisas Sociais, 2012. p. 147-167. Scielo Books.

UNESCO. Orientações técnicas de educação em sexualidade para o cenário brasileiro: tópicos e objetivos de aprendizagem. Brasília: UNESCO, 2013.

VIANNA, C. P.; UNBEHAUM, S. O gênero nas políticas públicas de educação no Brasil: 1988-2022. Cadernos de Pesquisa. São Paulo, v. 34, n. 121, p. 77-104, jan./abr., 2004. Scielo Brasil.

VIEIRA, P. M.; MATSUKURA, T. S. Modelos de educação sexual na escola: concepções e práticas de professores do ensino fundamental da rede pública. Revista Brasileira de Educação. Rio de Janeiro, v. 22, n. 69, p. 453-474, abr./jun., 2017. Scielo Brasil.

VILLARINHO, M. V.; PADILHA, M. I. Sentimentos relatados pelos trabalhadores da saúde frente à epidemia da AIDS (1986-2006). Texto contexto - enfermagem. Santa Catarina, vol. 25, n. 1, p. 1-9, mar., 2016. Scielo Brasil.

Revista Páginas de Filosofia, v. 10, n. 1, p. 137-171, jan.-jun. 2021 